\title{
The recent evolution of Liligo glacier, Karakoram, Pakistan, and its present quiescent phase
}

\author{
Marco BELÒ, ${ }^{1}$ Christoph MAYER,${ }^{2}$ Claudio SMIRAGLIA, ${ }^{1}$ Andrea TAMBURINI ${ }^{3}$ \\ ${ }^{1}$ Department of Earth Sciences 'Ardito Desio', University of Milan, Via Mangiagalli 34, I-20133 Milan, Italy \\ E-mail: marco_belo@trimble.com \\ ${ }^{2}$ Commission for Glaciology, Bavarian Academy of Sciences and Humanities, Alfons-Goppel Strasse 11, \\ D-80539 Munich, Germany \\ ${ }^{3}$ CESI S.p.A., Via Rubattino 54, I-20134 Milan, Italy
}

\begin{abstract}
Liligo glacier, in the central eastern Karakoram, Pakistan, is a small, south-to-north-flowing glacier situated in a transverse valley on the left (south) side of Baltoro glacier. New processing of satellite imagery enables a better quantification of terminus oscillations over the past 30 years. From the beginning of the 1970s to the beginning of the 21 st century, Liligo glacier advanced about $2 \mathrm{~km}\left(60 \mathrm{~m} \mathrm{a}^{-1}\right)$. The progress was characterized by a significant evolution of terminus morphology, similar to that observed on the same glacier during the advance event near the beginning of the 20th century, and to those of many other Karakoram glaciers. This suggests indications of a surge-type mechanism. Field observations performed in $\mathbf{2 0 0 4}$ indicated there was probably no confluence at that time between Liligo and Baltoro glaciers and that a quiescent phase had started in the early years of the 21st century.
\end{abstract}

\section{INTRODUCTION AND PREVIOUS KNOWLEDGE}

Liligo glacier, in the central eastern Karakoram, Pakistan, is a small, narrow glacier about $17 \mathrm{~km}$ long, situated in a transverse valley on the left side of Baltoro glacier about $7 \mathrm{~km}$ upstream of the glacier snout $\left(35.7^{\circ} \mathrm{N}, 76.21^{\circ} \mathrm{E}\right.$; Fig. 1). Liligo glacier terminus variations since 1892 have been reconstructed using a variety of methods and sources (historical documents, cartography, photographs, satellite images and field surveys) (Pecci and Smiraglia, 2000; Diolaiuti and others, 2003).

From the work of W. Conway in 1892 to A. Desio's investigations in 1969, we have abundant iconographic, cartographic and other documentary material demonstrating that Liligo glacier experienced an advance phase between the end of the 19th century and the first few decades of the 20th century, followed by a retreat phase lasting at least to the beginning of the 1970s. A splendid and well-known photograph taken by V. Sella in 1909 shows the terminus of the glacier at a point fairly close to the margin of Baltoro glacier (De Filippi, 1912), with a high ice cliff and icefall cones evident at the base; the tongue appears to be heavily crevassed, with broken masses of dirty ice.

The morphology observed by Desio in 1929 (SavoiaAosta and Desio, 1936) is completely different. The frontal sector of the glacier is narrow and thin and is hidden beneath glacial debris in the lowest part. The glacier appears to have retreated until the 1950s, when Desio's observations indicate a terminal position far back in the valley, almost $2 \mathrm{~km}$ from Baltoro glacier (Desio, 1991). The beginning of the new advance phase cannot be determined precisely. The data available and photographs taken during different field campaigns, as well as satellite images, indicate that from the early 1970 s to the start of the 21 st century the glacier was advancing again. Using a series of satellite images covering the period 1973-2001 (Landsat multispectral scanner (MSS), Landsat Thematic Mapper (TM), Advanced Spaceborne Thermal Emission and Reflection Radiometer (ASTER)), Kargel and others (2005) describe Liligo glacier as an example of a rapidly advancing Karakoram glacier and note that the reconnection of the Liligo glacier tributary to Baltoro glacier took place in 2001. The reconnection is defined as a type III junction, i.e. a bulging tributary with $R_{\mathrm{a}}>1$ (tributary flow faster than trunk).

The glacier experienced at least two advance phases (at the beginning and at the end of the 20th century), separated by a long period of stagnation and retreat (Pecci and Smiraglia, 2000). The surface morphology (heavily crevassed surface and steep terminus wall, rising tongue elevation) during the advance phases and information from historical sources indicate a surge-type mechanism (Hewitt, 1998; Diolaiuti and others, 2003).

Surging glaciers are a well-known phenomenon and characterize considerable parts of the glaciation in the Karakoram (Hewitt, 1969, 2005; Barrand and Murray, 2006). Reports indicate a total of 34 surges involving 23 glaciers from 1860 to the present (Hewitt, 1998, 2007). Many of the affected glaciers are tributaries of major valley glaciers, which show no signs of contemporary surges. The number of surges seems to have increased since 1985, and a concentration of surges has been observed over the last decade in the tributary glaciers of Panmah glacier, where three tributary glaciers surged in quick succession between 2001 and 2005 (Hewitt, 2007).

Our aim is to provide new information about the recent evolution of the lower sector of Liligo glacier. In particular, we wish to improve the quantification of the advance phase of the terminus by means of new satellite pictures, and to verify its present status with new direct field measurements. Field data were collected in summer 2004 during the expedition 'K2 2004 - 50 years later', whose main objective was to investigate Baltoro glacier and characterize its ablation sector and existing relationships between ablation, meteorological conditions and debris cover (Mayer and others, 2006; Mihalcea and others, 2006, 2008).

\section{METHODS}

Indirect and direct in-field methods have been applied on Liligo glacier in order to compute recent terminus variations 


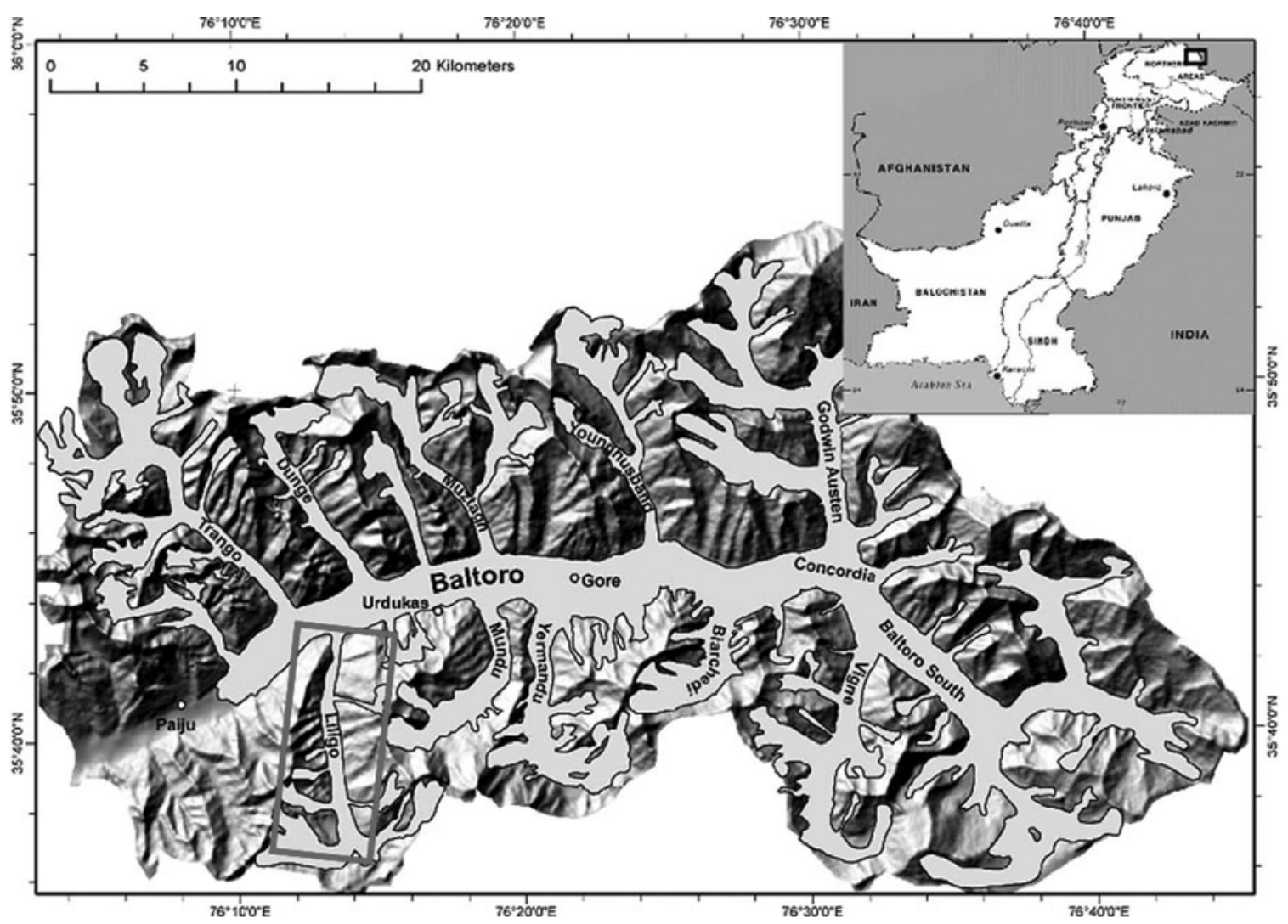

Fig. 1. Overview of the Baltoro drainage basin, and the location of Liligo glacier.

and analyze the present morphology. The available database of satellite pictures, containing the Système Probatoire pour I'Observation de la Terre (SPOT) 1986 image already used by Diolaiuti and others (2003), has been enriched with new satellite images: Corona 1971, 1979 and 1980, Landsat 1999 and ASTER 2001.

The pixel size of the different imagery varies between 3 and $28.5 \mathrm{~m}$. Relative rectification of the Corona images (pixel size: 3 and $8 \mathrm{~m}$ ) results in relative accuracies of the terminus delineation of two pixels. In respect to co-registration to an ASTER ortho-image from 2001, the accuracy of the glacier delineation is as good as one pixel of the master image $(15 \mathrm{~m})$. The larger pixel size of the Lansdat TM images $(28.5 \mathrm{~m})$ therefore constitutes the maximum error for the localization of the glacier margin.

The field campaign was performed with threedimensional (3-D) laser and global positioning system (GPS) geodetic L1/L2 Trimble receivers. The laser scanner was used to reconstruct a 3 -D model of the glacier terminus, to collect detailed information about the glacier snout morphology and to realize a time benchmark for comparison with future field investigations. This will provide detailed information about volume and area variations in the future. Geodetic GPS receivers were used to determine control points, allowing matching of the different scans obtained by the laser, and to define the exact position of the glacier terminus.

Kinematic GPS measurements were also used to precisely define the terminus boundaries. For that purpose, a GPS master station was set up in the vicinity of Khoburtze camp $\left(35.71^{\circ} \mathrm{N}, 76.23^{\circ} \mathrm{E} ; 3825 \mathrm{~m}\right.$ a.s.l.) for the real-time kinematic measurements. The raw GPS observations were also recorded for subsequent georeferencing of the survey data in the Universal Transverse Mercator zone $43 \mathrm{~N}$ projection on the World Geodetic System 1984 (WGS84) datum. Due to the lack of a GPS permanent station or benchmark of the Survey of Pakistan in the area, it was not possible to refer the master station coordinates in the global reference system with accuracy in the centimetre range. The GPS error corresponds to an absolute error in the range of metres, which, however, is acceptable considering the level of inaccuracy characterizing the available maps and the pixel resolution of the satellite images. As there are no levelling points or recent gravimetric measurements for this region, the Earth Gravitational Model 1996 (EGM96) values were used as references for the altitudes.

The GPS data of the terminus boundary were marked on the 2001 ASTER image, and the Baltoro glacier boundary was also identified on this image. Geographical Information System (GIS)-based software was used to compute the distance between the southern margin of Baltoro glacier and the terminus of Liligo glacier as measured in 2004.

A detailed digital elevation model (DEM) of the glacier surface, with a $0.5 \mathrm{~m}$ cell size, was obtained after processing each point cloud with the Golden Software Surfer 8 inverse distance weighting method (Fig. 2). A detailed map of the glacier snout was obtained by contouring the DEM of the glacier surface. It would be interesting to compare the DEMs obtained by laser data and by software elaboration of the available satellite imagery. Some investigations have been done in this direction, but the resolution achievable from available ASTER images is insufficient for this kind of comparison. Besides, Shuttle Radar Topography Mission (SRTM) imagery is not available for this glacier, and the ASTER DEM seems highly distorted due to the steep lateral walls. The rather inhomogeneous terrain of the narrow Liligo 


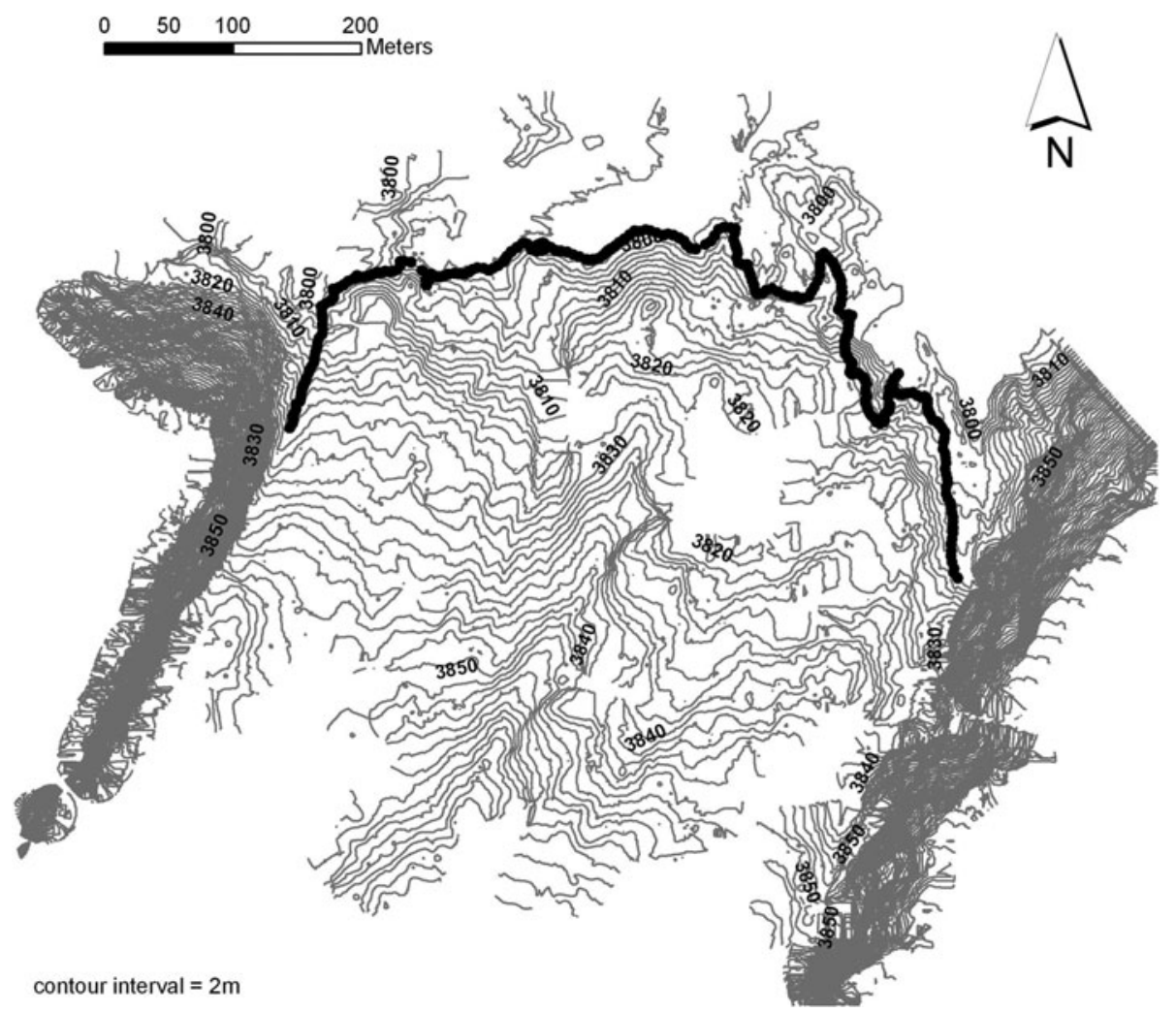

Fig. 2. Contour map of Liligo glacier snout derived from laser scans. GPS measurements (black path) corresponding to the snout limit are merged with the map.

valley would only allow a few pixels from the ASTER image to be compared with the 3-D data obtained by field measurement.

\section{RESULTS}

The elaboration of 1968-81 Corona satellite imagery and of other more recent SPOT, Landsat and ASTER images allows precise reconstruction of the evolution of the glacier's lower sector over the last three decades of the 20th century. The 1971 Corona image shows the Liligo terminus still well within the tributary valley, at a position probably very similar to that observed by Desio in the 1950s. The distance from the Baltoro glacier margin is about $2.1 \mathrm{~km}$ (in the 1968 image, the Liligo terminus is scarcely visible, but its position does not appear to differ greatly from that in 1971). The lower sector of the tongue is completely covered with debris for about 500-600 m starting from the terminus. The braided glacial stream is clearly visible down to the confluence with the main valley, where it forms small lakes and then flows down the left side of the glacier. Although the general morphology shows no changes in the 1979 and 1980 Corona images, the continuous debris cover extends for more than $1 \mathrm{~km}$ down the tongue, and the distance from Baltoro glacier decreases to about $1.7-1.8 \mathrm{~km}$.

In the 1986 SPOT image, the terminus continues to advance (to a position about $1.4 \mathrm{~km}$ from Baltoro glacier), and in the 1999 Landsat image Liligo glacier appears to be very close to Baltoro glacier (in 1997 a minimum distance of $50 \mathrm{~m}$ was measured in the field using a telemeter) (Diolaiuti and others, 2003). The terminus has changed markedly during this period and now displays a very steep front broken up by crevasses. Over the course of about 30 years, the terminus advanced about $2 \mathrm{~km}$, with rapid thickening of the terminus itself, along with a breaking-up of the glacier surface. The situation in the 2001 ASTER image is not very different: the Liligo terminus appears to have reached a position just a few tens of metres from the margin of Baltoro glacier in its left sector. In the right sector, a plain between the two glaciers spans a width of several hundred metres and is partially occupied by a lake. Therefore, it is quite likely that a true conjunction between Liligo and Baltoro glaciers has never taken place (Fig. 3). For five points, with an azimuth of approximately $195^{\circ}$ northeast from the terminus, the distance between the Liligo glacier terminus and Baltoro glacier was calculated and shown to range between about $60 \mathrm{~m}$ in the left sector and about $250 \mathrm{~m}$ in the right sector where the proglacial lake is found. The terminus variations of Liligo glacier as derived from the satellite images are given in Table 1 and Figure 4.

The field observations show that in the summer of 2004 the two glaciers were clearly separated by a proglacial plain that was partially occupied by a lake. These measurements also indicate that there has been no marked change in the minimum distance between Liligo and Baltoro glaciers, compared to the last field measurements in 1997, which revealed a minimum distance of $50 \mathrm{~m}$ (in the left sector of the terminus). Since 1997, the morphology of the terminus has changed considerably. In 1996 and 1997 the terminus was steep and bulging; the surface was severely broken and consisted almost entirely of seracs and dirty ice, especially in the righthand sector. Due to the presence of numerous crevasses, the surface was not entirely covered with debris and there were bands of clean ice with clearly visible shear planes. Even if fragmented by crevasses, the surface looked almost flat. The contact with the proglacial lake was marked 

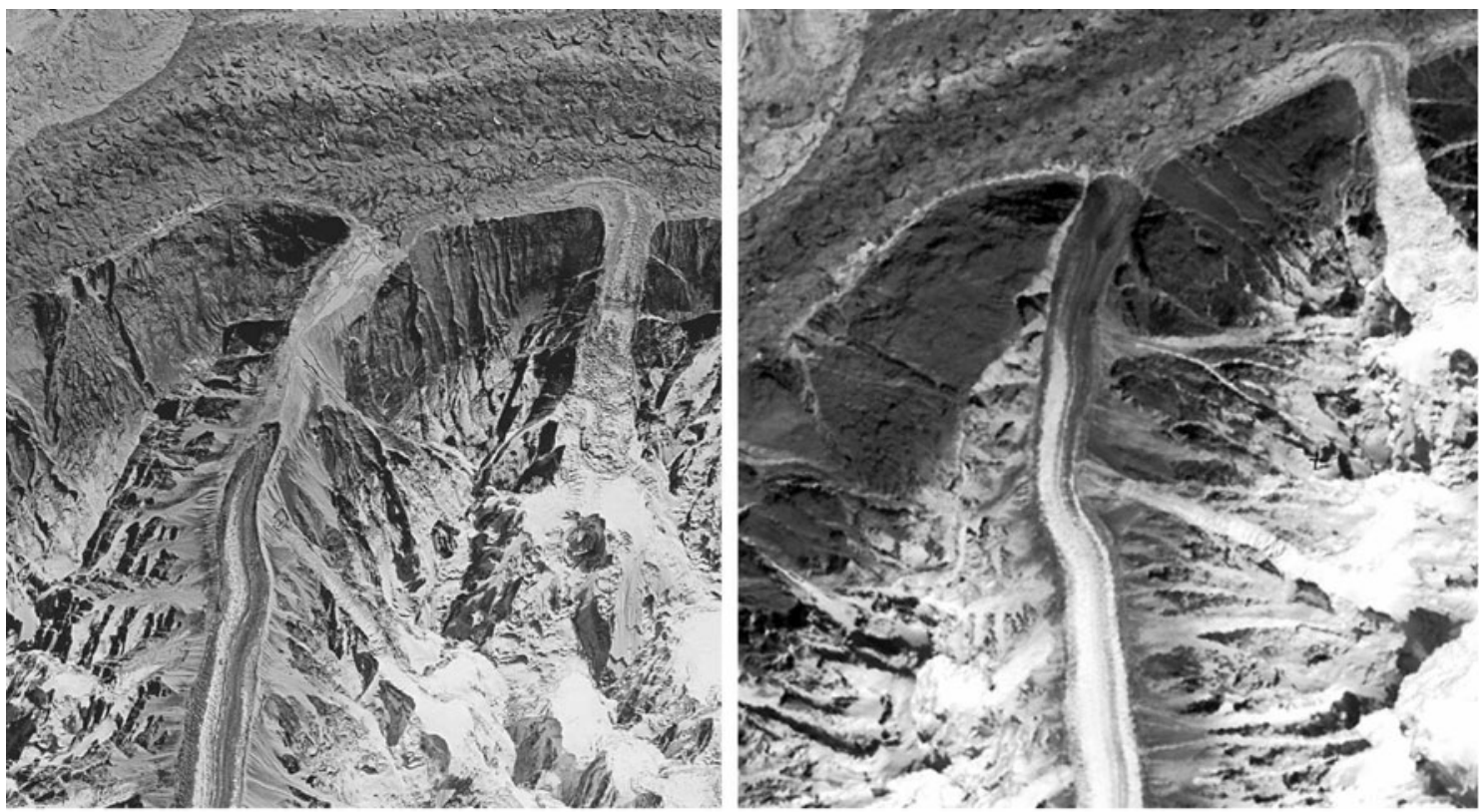

$2000 \mathrm{~m}$

Fig. 3. Liligo glacier snout positions in 1971 (left; Corona) and 2001 (right; ASTER).

by an almost vertical cliff which at some points rose to a height of about $10 \mathrm{~m}$ (Fig. 5a). In 2004, the terminus was gently sloping upstream with an average inclination of about $18^{\circ}$, as determined from the DEM. It was almost entirely debris-covered, no crevasses are visible and the tongue is thin and no longer bulging (Fig. 5b). Significant height differences on the surface originate from differential ablation. Particularly evident is a large medial moraine in the central sector of the glacier. Moreover the shape of the terminus perimeter is no longer straight but, as shown in the map, is interrupted by different lobes gently descending towards and into the proglacial lake

\section{DISCUSSION}

The field and remote-sensing data clearly show that Liligo glacier experienced a marked advance (of about $2.1 \mathrm{~km}$ ) between the beginning of the 1970s and the first few years of the 21 st century. They indicate a yearly mean advance of about $60 \mathrm{~m}$. However, this advance accelerated after the $1980 \mathrm{~s}$ and reached values of more than $100 \mathrm{~m} \mathrm{a}^{-1}$ in the 1990s. Taking into account the morphology of the advancing terminus as well, this phenomenon has been described as a surge (Hewitt, 1998; Diolaiuti and others, 2003), and considering the comparatively low advance rates has been termed a 'slow surge' (Kargel and others, 2005). At the end of the 1990s and in the first few years of the 21 st century, the glacier probably reached its maximum extent as it came to within a few tens of metres of Baltoro glacier, although it does not appear that an actual contact and merging of the two flows occurred. Although the terminus position did not change much up to 2004, the change in the terminus morphology compared to the years before indicates that the advance phase had ended and that the glacier entered a new phase of stagnation. This would confirm an interval of about 80-90 years between the two maximum stages of the surge, assuming, however, that Sella's 1909 photograph does represent a situation very close to the maximum glacier expansion of the early 20th century. The period of stagnation (post-surge adjustment (Hewitt, 2007)) has probably been in progress for several years. It should soon lead to the fragmentation of the lower tongue sector and to its retreat up-valley, which was the situation shown in Desio's 1929 and 1953 photographs.

A discussion of the complex and still unresolved issues concerning galloping glaciers (e.g. the development of

Table 1. Terminus variations of Liligo glacier obtained from satellite data and from field measurements

\begin{tabular}{|c|c|c|c|c|c|}
\hline Satellite image & Date & $\begin{array}{c}\text { Distance from Baltoro } \\
\mathrm{m}\end{array}$ & $\begin{array}{l}\text { Variation } \\
\qquad \mathrm{m}\end{array}$ & $\begin{array}{c}\text { Relative error } \\
\mathrm{m}\end{array}$ & $\begin{array}{c}\text { Annual mean variation } \\
\mathrm{m}\end{array}$ \\
\hline Corona DS1115 & 16 Sept. 1971 & $\sim 2100$ & - & - & - \\
\hline Corona DZB1215 & 1979 & $\sim 1810$ & $\sim+290$ & \pm 16 & $\sim+36$ \\
\hline Corona DZB1216 & 22 Jun. 1980 & $\sim 1730$ & $\sim+370$ & \pm 16 & $\sim+80$ \\
\hline SPOT 1 HRV1 201-278 & 22 Jun. 1986 & $\sim 1400$ & $\sim+700$ & \pm 16 & $\sim+55$ \\
\hline Landsat TM & 1999 & $\sim 50(1997$ field data $=50)$ & $\sim+2050$ & \pm 30 & $\sim+103$ \\
\hline ASTER & 2001 & $\sim 60(2004$ field data $=58)$ & $\sim+2040$ & \pm 25 & $\sim-5$ \\
\hline
\end{tabular}




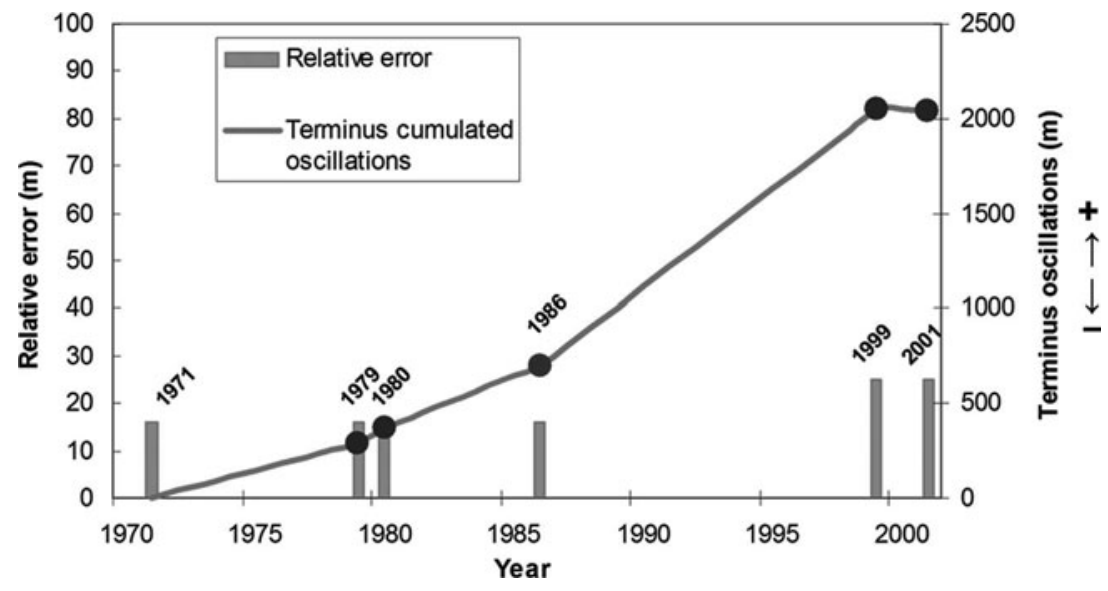

Fig. 4. Cumulated oscillation graph of Liligo glacier. The distance between Liligo glacier terminus and Baltoro glacier is used as a reference.

theories by Meier and Post, 1969; Raymond, 1987; Paterson, 1994; Harrison and Post, 2003) does not lie within the scope of this paper. We are interested in the question whether Liligo glacier is a surging glacier, as claimed by others (Hewitt, 1998; Diolaiuti and others, 2003). There are many examples of glacier advances that are not surges. On the other hand, not all glacier surges result in an advance.

For Liligo glacier, information is lacking about speed variations and fast volume variations in the ablation area and accumulation basins, so it seems difficult to include this glacier in the Meier and Post (1969) classification. Basal morphology and the internal hydraulic system information are missing, as well as morphological features such as looped or contorted moraines that are diagnostic of surge behaviour (Dowdeswell and Williams, 1997; Barrand and Murray, 2006).
It is clear that the number of data available and the characteristics of Liligo glacier itself differentiate it from archetypical surging glaciers (e.g. Variegated Glacier, Alaska, USA (Kamb and others, 1985; Lawson, 1997)). Karakoram glacier surges involve glaciers situated in climatic and geomorphological contexts different from the environments of Alaska, Iceland or the Svalbard archipelago, where this glacier type has been studied in detail.

For Liligo glacier, in addition to the rapid advance phase of the 1990s, the terminus morphology is one of the most significant indicators of possible surge-type behaviour. The heavily crevassed steep slope of the glacier snout visible in the pictures available early last century is an element supporting classification of Liligo glacier as surge-type. The same kind of morphology has been observed on other Karakoram glaciers where surge events have been directly
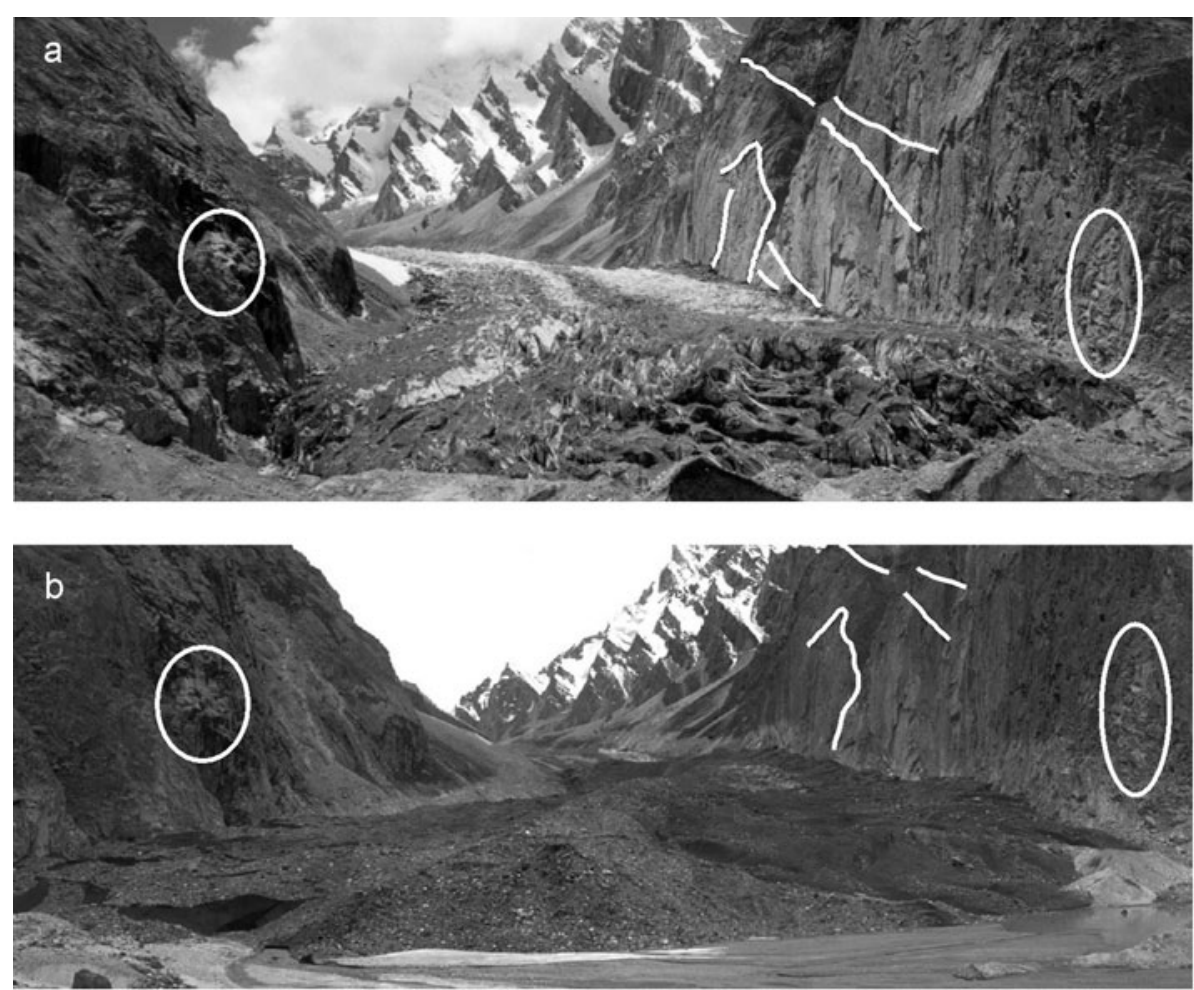

Fig. 5. Liligo glacier snout in 1997 (a) (photo by M. Pecci) and 2004 (b) (photo by A. Tamburini). Some rock structures are highlighted for comparison. The proglacial lake is visible in (b). 
observed and studied (e.g. Kuthia glacier (Desio, 1954); Shingchukpi glacier (Hewitt, 2007)). The question thus remains open; whether Liligo glacier is a surging glacier will be better understood when data from further remotesensing and field investigations become available.

\section{CONCLUSION}

Processing of new satellite imagery (Corona, Landsat and ASTER) enabled a better quantification of Liligo glacier terminus oscillations over the last 30 years. We have confirmed that between the beginning of the 1970s and the beginning of the 21st century, Liligo glacier advanced about $2 \mathrm{~km}\left(60 \mathrm{~m} \mathrm{a}^{-1}\right)$, with an increase in speed in the 1990s $\left(100 \mathrm{~m} \mathrm{a}^{-1}\right)$. This phase was characterized by a significant evolution of terminus morphology, marked by increasing glacier thickness and heavy crevassing. The glacier's steep wall shape is similar to that observed on Liligo glacier during the advance event of the beginning of the 20th century, and on many other tributary glaciers of the Karakoram that have shown surge dynamics characteristics.

The summer 2004 GPS and laser scanner field surveys provided data for the computation of a DEM of the terminus area which provides a basis for comparison with future glacier retreat. Field surveys have indicated variations in the morphology of the glacier terminus, levelled and debriscovered. Large medial moraines have formed immediately behind the snout, showing intense differential ablation activity and a reduction in ice contribution from the accumulation basin. Field observations have indicated that no confluence between Liligo and Baltoro glaciers occurred during the advance phase, which ended in the very early years of the 21 st century as the current quiescent phase started.

\section{ACKNOWLEDGEMENTS}

This study was carried out within the framework of the Ev-K ${ }^{2}-C N R$ 'Scientific and Technological Research in Himalaya and Karakoram' project and in the framework of the scientific-mountaineering project 'K2 2004 - 50 years later' (Glaciology Research Group, leader C. Smiraglia). The research was made possible by contributions from the IMONT (Italian Mountain Institute) and from the 2005 MIUR (Ministero Istruzione, Università, Ricerca) Cofin programme 'Increasing rate of climate change impacts on high mountain areas'. We thank J. Shroder, B. Raup and an anonymous reviewer for their critical revision and for making useful suggestions about the manuscript.

\section{REFERENCES}

Barrand, N.E. and T. Murray. 2006. Multivariate controls on the incidence of glacier surging in the Karakoram Himalaya. Arct. Antarct. Alp. Res., 38(4), 489-498.
De Filippi, F. 1912. La spedizione di S.A.R. il Principe Luigi Amedeo di Savoia Duca degli Abruzzi nel Karakorum e nell'Himalaya occidentale (1909). Bologna, Zanichelli.

Desio, A. 1954. An exceptional advance in the Karakoram-Ladakh region. J. Glaciol., 2(16), 383-385.

Desio, A. 1991. Italian expedition to the Karakorum (K2) and Hindu Kush. Scientific Report 1 - Geography. Milan, Istituto Italiano per il Medio ed Estremo Oriente.

Diolaiuti, G., M. Pecci and C. Smiraglia. 2003. Liligo Glacier, Karakoram, Pakistan: a reconstruction of the recent history of a surge-type glacier. Ann. Glaciol., 36, 168-172.

Dowdeswell, J.A. and M. Williams. 1997. Surge-type glaciers in the Russian High Arctic identified from digital satellite imagery. J. Glaciol., 43(145), 489-494.

Harrison, W. and A. Post. 2003. How much do we really know about glacier surging? Ann. Glaciol., 36, 1-6.

Hewitt, K. 1969. Glacier surges in the Karakoram Himalaya (Central Asia). Can. J. Earth Sci., 6(4), Part 2, 1009-1018.

Hewitt, K. 1998. Glaciers receive a surge of attention in the Karakoram Himalaya. Eos, 79(8), 104-105.

Hewitt, K. 2005. The Karakoram anomaly? Glacier expansion and the 'elevation effect', Karakoram Himalaya. Mt. Res. Dev., 25(4), $332-340$

Hewitt, K. 2007. Tributary glacier surges: an exceptional concentration at Panmah Glacier, Karakoram Himalaya. J. Glaciol., 53(181), 181-188.

Kamb, B. and 7 others. 1985. Glacier surge mechanism: 19821983 surge of Variegated Glacier, Alaska. Science, 227(4686), 469-479.

Kargel, J.S. and 16 others. 2005. Multispectral imaging contributions to global land ice measurements from space. Remote Sens. Environ., 99(1-2), 187-219.

Lawson, W. 1997. Spatial, temporal and kinematic characteristics of surges of Variegated Glacier, Alaska. Ann. Glaciol., 24, 95-101.

Mayer, C., A. Lambrecht, M. Belò, C. Smiraglia and G. Diolaiuti. 2006. Glaciological characteristics of the ablation zone of Baltoro glacier, Karakoram, Pakistan. Ann. Glaciol., 43, 123-131.

Meier, M.F. and A. Post. 1969. What are glacier surges? Can. J. Earth Sci., 6(4), 807-817.

Mihalcea, C., C. Mayer, G. Diolaiuti, A. Lambrecht, C. Smiraglia and G. Tartari. 2006. Ice ablation and meteorological conditions on the debris-covered area of Baltoro glacier, Karakoram, Pakistan. Ann. Glaciol., 43, 292-300.

Mihalcea, C. and 7 others. 2008. Spatial distribution of debris thickness and melting from remote-sensing and meteorological data, at debris-covered Baltoro glacier, Karakoram, Pakistan. Ann. Glaciol., 48 (see paper in this volume).

Paterson, W.S.B. 1994. The physics of glaciers. Third edition. Oxford, etc., Elsevier.

Pecci, M. and C. Smiraglia. 2000. Advance and retreat phases of the Karakorum glaciers during the 20th century: case studies in Braldo Valley (Pakistan). Geogr. Fís. Din. Quat., 23(1), 73-85.

Raymond, C.F. 1987. How do glaciers surge? A review. J. Geophys. Res., 92(B9), 9121-9134.

Savoia-Aosta, A. and A. Desio. 1936. Spedizione geografica italiana al Karakoram (1929): storia del viaggio e risultati geografici. Milan, Bertarelli.

Wake, C.P. and M.P. Searle. 1993. Correspondence. Rapid advance of Pumarikish Glacier, Hispar Glacier Basin, Karakoram Himalaya. J. Glaciol., 39(131), 204-206. 